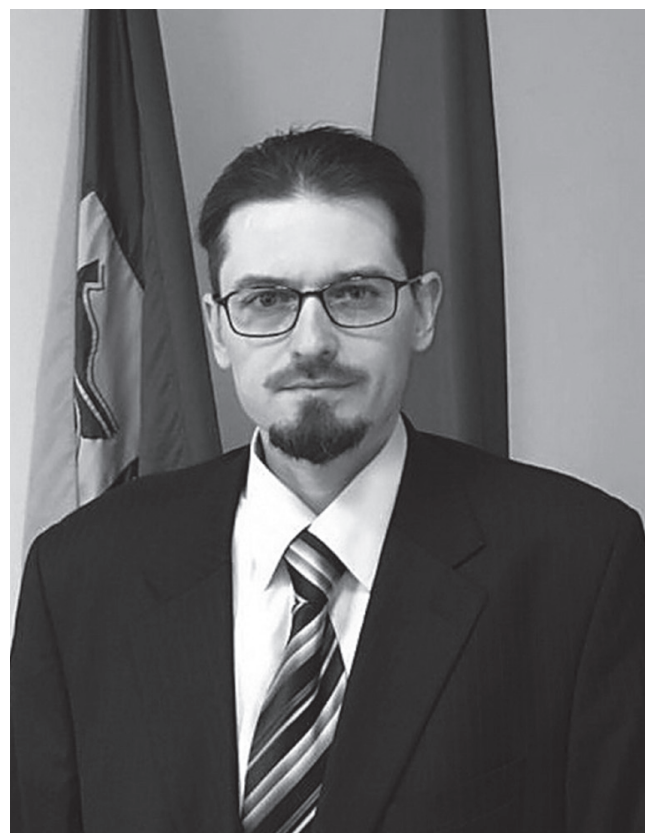

DOI https://doi.org/10.32689/2617-2224-

2019-16-1-110-123

UDC: 378.014 (477)

Мартииин Денис Сергійович, кандидат наук з богослов'я, завідувач кафедри українознавства, православ'я та теологї, Міжрегіональна Академія управління персоналом, 03039, м. Київ, вул. Фрометівська, 2, тел.: (098) 56165 63, e-mail: mdsdenim@ukr.net

ORCID: 0000-0002-2770-7757

Мартышин Денис Сергеевич, кандидат наук по богословию, заведующий кафедрой украиноведения, православия и теологии, Межрегиональная Академия управления персоналом, 03039, 2. Киев, ул. Фрометовская, 2, тел.: (098) 56165 63,e-mail: mdsdenim@ukr.net.

ORCID: 0000-0002-2770-7757

Martyshyn Denys Serhiiovych,

candidate sciences in theology, head of the Department of Ukrainian Studies, Orthodoxy and Theology, Interregional Academy of Personnel Management, 03039, Kyiv, Str. Frometivska, 2, tel.: (098) 56165 63, e-mail: mdsdenim@ukr.net

ORCID: 0000-0002-2770-7757

\title{
ІНФОРМАЦІЙНО-КОМУНІКАТИВНА ПОЛІТИКА ЯК ІНСТРУМЕНТ ПОСИЛЕННЯ ВЗАЄМОДІї ДЕРЖАВИ ТА ЦЕРКВИ
}

Анотація. Розглядається одна з актуальних тем в державному управлінні - розвитку та посиленню конструктивної взаємодії Церкви та держави. Важливим фактором діалогу держави та релігійних організацій є інформаційно-комунікативна політика.

Доцільність аналізу сучасного стану взаємовідносин держави та Церкви в Україні підтверджується необхідністю розроблення нових моделей державно-церковних відносин, які б відповідали вимогам сучасної демократичної країни та розвиненого громадянського суспільства. Після краху атеїстичного режиму Радянського Союзу, в умовах процесів глобалізації, всебічного впровадження інформаційних технологій та встановлення гуманістичної концепції розвитку людства, релігійна проблематика осмислення буття набуває нового значення. Розвиток церковної комунікації у цій новій духовній, соціальній, економічній та політичній реальності зазнає певної трансформації. Поглиблення релігійності, духовності й моральності сучас- 
ної людини - стають складовою системи державного управління, а взаємовідносини Церкви та держави - необхідною життєвою умовою для подальшого розвитку сучасного світу. Без урахування релігійного чинника державі важко вибудувати гармонійну систему суспільних відносин.

Актуальні питання взаємовідносин держави та Церкви залишаються ключовими для державного управління. Саме тому необхідно визначити основні контури інформаційно-комунікативної політики, теоретико-методологічні засади взаємовідносин держави та релігійних організацій. Така проблематика набуває важливого значення у контексті посилення впливу Християнських Церков України на процеси розбудови демократичного суспільства.

Актуальність цієї теми обумовлена тим фактом, що проблеми взаємовідносин держави та Церкви постійно перебувають у фокусі державних керманичів, лідерів політичних партій, церковних ієрархів та науковців. Інформаційно-комунікативна політика держави у сфері релігії була і залишається темою постійних дискусій між теоретиками та практиками державного управління.

У ході аналізу визначено, що інформаційно-комунікативна політика держави у сфері релігії та розвиток самої церковної комунікації мають великі можливості. Однак, науковцями та управлінцями недостатньо враховується безпосередній вплив Церкви на життя українського суспільства. Зокрема, автор вказує напрями розширення діалогу Церкви та держави. Детально вивчено види церковної комунікації. Визначено, що ефективна організація церковної комунікації та інформаційно-комунікативна політика держави у сфері релігії, яка відповідає принципам демократії, свободи слова та віросповідань сприяє суттєвому зміцненню духовної єдності народу.

Запропоновано шляхи вирішення можливих проблем розвитку церковної комунікації. На сучасному етапі розвитку української держави, через виникнення політичних і соціальних проблем, напруженості у суспільстві зросла також необхідність інтегрованості релігії, християнської теології, соціального вчення Церкви у процеси державотворення. Водночас виникнення глобальних проблем людства спонукає до необхідності застосування синергї релігії та науки, пошуку способів розв’язання світових конфліктів шляхом об’єднання зусиль представників релігії, держави, політичних сил та громадянського суспільства. Виходячи з цього, постала значна необхідність у постійному діалозі Церкви та держави.

Ключові слова: діалог, взаємодія, комунікація, держава, інформаційно-комунікативна політика, соціальне вчення Церкви, місія, релігія, громадянське суспільство, свобода, демократія.

\section{ИНФОРМАЦИОННО-КОММУНИКАТИВНАЯ ПОЛИТИКА КАК ИНСТРУМЕНТ УКРЕПЛЕНИЯ ВЗАИМОДЕЙСТВИЯ ГОСУДАРСТВА И ЦЕРКВИ}

Аннотация. Рассматривается одна из актуальных тем в государственном управлении - развитие и укрепление конструктивного взаимодействия 
Церкви и государства. Важным фактором диалога государства и религиозных организаций является информационно-коммуникативная политика.

Целесообразность анализа современного состояния взаимоотношений государства и Церкви в Украине подтверждается необходимостью разработки новых моделей государственно-церковных отношений, соответствующих требованиям современной демократической страны и развитого гражданского общества. После краха атеистического режима Советского Союза, в условиях процессов глобализации, всестороннего внедрения информационных технологий и установления гуманистической концепции развития человечества, религиозная проблематика осмысления бытия приобретает новое значение. Развитие церковной коммуникации в этой новой духовной, социальной, экономической и политической реальности испытывает определенную трансформацию. Углубление религиозности, духовности и нравственности современного человека - становятся частью системы государственного управления, а взаимоотношения Церкви и государства необходимым жизненным условием дальнейшего развития современного мира. Без учета религиозного фактора государству трудно выстроить гармоничную систему общественных отношений.

Актуальные вопросы взаимоотношений государства и Церкви остаются ключевыми для государственного управления. Именно поэтому так важно определить основные контуры информационно-коммуникативной политики, теоретико-методологические основы взаимоотношений государства и религиозных организаций. Такая проблематика приобретает важное значение в контексте усиления влияния Христианских Церквей Украины на процессы развития демократического общества.

Актуальность этой темы обусловлена тем фактом, что проблемы взаимоотношений между государством и Церковью постоянно находятся в фокусе государственных руководителей, лидеров политических партий, церковных иерархов и ученых. Информационно-коммуникативная политика государства в сфере религии была и остается темой постоянных дискуссий между теоретиками и практиками государственного управления.

В ходе анализа определено, что информационно-коммуникативная политика государства в сфере религии и развитие самой церковной коммуникации имеют большие перспективы. Однако учеными и управленцами недостаточно учитывается непосредственное влияние Церкви на жизнь украинского общества. Кроме этого, автор указывает направления расширения диалога Церкви и государства. Подробно изучены виды церковной коммуникации. Определено, что эффективная организация церковной коммуникации и информационно-коммуникативная политика государства в сфере религии, соответствующая принципам демократии, свободы слова и вероисповедания способствует существенному укреплению духовного единства народа.

Предложены пути решения возможных проблем развития церковной коммуникации. На современном этапе развития украинского государства из-за возникновения политических и социальных проблем, напряженности 
в обществе возросла также необходимость интеграции религии, христианской теологии, социального учения Церкви в процессы государственного строительства. Одновременно возникновение глобальных проблем человечества подводит к необходимости применения синергии религии и науки, поиска способов решения мировых конфликтов путем объединения усилий представителей религии, государства, политических сил и гражданского общества. Исходя из этого, возникла большая необходимость в постоянном диалоге Церкви и государства.

Ключевые слова: диалог, взаимодействие, коммуникация, государство, информационно-коммуникативная политика, социальное учение Церкви, миссия, религия, гражданское общество, свобода, демократия.

\section{INFORMATIONAL AND COMMUNICATIVE POLICY AS AN INSTRUMENT FOR STRENGTHENING OF INTERACTION OF STATE AND CHURCH}

Abstract. This article is devoted to one of the topical issues in state governance - the development and strengthening of constructive interaction between the Church and the state. An important factor in the dialogue between the state and religious organizations is the information and communicative policy.

The expediency of analyzing the current state of relations between the state and the Church in Ukraine is confirmed by the need to develop new models of statechurch relations that meet the requirements of a modern democratic country and a developed civil society. After the collapse of the atheistic regime of the Soviet Union, in the context of globalization processes, the comprehensive introduction of information technologies and the establishment of a humanistic concept of the development of mankind, religious problems of understanding life take on new meaning. The development of church communication in this new spiritual, social, economic and political reality is experiencing a certain transformation. The deepening of religiosity, spirituality and morality of a modern person becomes a part of the system of government, and the relationship between the Church and the state is a necessary condition for the further development of the modern world. Without taking into account the religious factor, it is difficult for the state to build a harmonious system of social relations.

The urgent issues of state and Church relations remain key to public administration. That is why it is so important to identify the main contours of information and communication policy, the theoretical and methodological principles of relations between the state and religious organizations. Such a problem becomes important in the context of the strengthening of the influence of the Christian Churches of Ukraine on the processes of building a democratic society.

The urgency of this topic is due to the fact that the problems of relations between the state and the Church are constantly in the focus of state leaders, leaders of political parties, church hierarchs and scholars. Information and communicative 
policy of the state in the field of religion was and remains the subject of constant discussions between theorists and practices of public administration.

In the course of the analysis, the author determines that the state's information and communicative policy in the field of religion and the development of the church communication themselves have great potential, but scientists and managers do not sufficiently take into account the direct influence of the Church on the life of Ukrainian society. In addition, the author points out ways to expand the dialogue between the Church and the state. The types of church communication are studied. It is determined that effective organization of church communication and information and communicative policy of the state in the field of religion, which corresponds to the principles of democracy, freedom of speech and beliefs, contribute to a significant strengthening of the spiritual unity of the people.

In conclusion, the author provides solutions to possible problems in the development of church communication. At the current stage of development of the Ukrainian state, due to the emergence of political and social problems and tensions in society, the need for the integration of religion, Christian theology, and the social doctrine of the Church in the processes of state formation has also increased. At the same time, the emergence of global problems of humanity leads to the need to use the synergy of religion and science, the search for solutions to world conflicts by combining the efforts of representatives of religion, state, political forces and civil society. Accordingly, the author points to the need for a permanent dialogue between the Church and the state.

Keywords: dialogue, interaction, communication, state, informational and communicative policy, social doctrine of the Church, mission, religion, civil society, freedom, democracy.

Постановка проблеми. Важливість та необхідність грунтовного науково-богословського осмислення питань церковної комунікації полягає в тому, що багатогранний розвиток релігійних громад, соціальна місія Церкви, розбудова демократичного й громадянського суспільства, вільний доступ віруючої людини до інформації, всебічні процеси глобалізації, модернізації є важливими факторами не лише розбудови сучасної демократичної держави, але й нових моделей релігійного буття.

Адже йдеться про духовну відповідальну позицію християнина за власну священну місію проголошення Свангелія, духовних цінностей християнства. Відомо, що поняття “комунікація" в сучасній науці є досить широко вживаним. Комунікацію науковці розглядають у контексті: “як систему, у якій здійснюється процес взаємодії та використовуються способи спілкування, що дають змогу створювати, передавати й приймати різноманітну інформацію” [1, c. 8].

Аналіз останніх досліджень та публікацій. Слід наголосити, що значний внесок у дослідження теоретичних проблем упровадження 
комунікативних концепцій та технологій в Україні зробили такі науковці: Г. Щокін, В. Козаков, О. Радченко, О. Антонова, Е. Афонін, В. Бебик, М. Білинська, В. Ребкало, В. Різун, Є. Романенко, А. Савков, С. Серьогін, Г. Ситник, I. Сурай, С. Телешун, I. Чаплай, Д. Кіслов, М. Головатий, О. Бухтатий.

У їхніх праціях окреслено потребу у розгляданні буття людської особистості, родини, держави та людства у безпосередньому зв'язку з Богом, Який теологією розглядається як володар Буття, і як причина Буття. Зрозуміло, що застосовуючи духовну парадигму життя, розвитку людства та богословський підхід у державному управлінні можна здійснити синтез, який передбачає звернення науковців до вивчення біблійного одкровення, соціального вчення Церкви, публічної й політичної теології.

На необхідність діалогу науки і релігії та формування інтегрованого науково-богословського світогляду звертають увагу західні християнські богослови: Г. Кюнг, Р. Хейз, Т. Райт, Р. Нібур, Д. Карсон, П. Нулленс, Р. Міченер, К. Деянг, П. Хелм, Д. Брей, П. Дженсен, Д. Маклеод, Е. Клауні, Р. Летем, С. Фергюсон, П. Пеннер, Й. Раймер, Р. Бакке, С. Честер, С. Хауервакс, Р. Кристофер, Д. Стотт, У. Брюггеман.

Значний внесок у дослідження теоретичних проблем комунікації Церкви, держави та українського суспільства зробили відомі науковці, зокрема: А. Колодний, М. Маринович, В. Бондаренко, В. Сленський, С. Здіорук, О. Саган, Л. Филипович, П. Яроцький, Р. Небо- жук, Ю. Чорноморець, А. Арістова, О. Недавня, Т. Гаврилюк, В. Шевченко, В. Петренко, П. Павленко, О. Бучма, М. Черенков, В. Чемерис, В. Сергійчук, Ф. Медвідь, Я. Грицак, М. Гетьманчук, А. Аржаковський, А. Зінченко, Г. Щокін, М. Головатий, Є. Романенко, О. Радченко, В. Пасічник, М. Пірен.

Багатогранні процеси комунікації Церкви $з$ державою, важливі питання державотворення, проблематика взаємодії Церкви та держави, питання інформаційно-комунікативного простору знайшли своє вагоме місце у роботах церковних діячів. Дослідження в цьому напрямі проводили митрополит Андрей (Шептицький), кардинал Йосиф (Сліпий), митрополит Володимир (Сабодан), патріарх Філарет (Денисенко), кардинал Любомир (Гузар), митрополит Святослав (Шевчук), митрополит Олександр (Драбинко), єпископ Борис (Гудзяк), архімандрит Кирило (Говорун), священик Петро Балог ОР.

Серед українських вчених, наукових установ, громадських об'єднань, які найбільше зробили для дієвої взаємодії релігії та суспільства, варто виокремити діяльність Української Асоціації релігієзнавців (А. Колодний), Центру дослідження релігій (В. Єленський), кафедри культурології факультету філософської освіти і науки Національного педагогічного університету імені М. П. Драгоманова (В. Бондаренко), Духовно-просвітницького центру імені святих апостолів при МАУП.

Проблеми інформаційно-комунікативної політики держави та церковної комунікації досить активно обговорюються на конференціях i 
наукових семінарах, але незважаючи на низку публікацій та фундаментальних досліджень з цієї тематики, ще й досі залишаються нерозкритими численні питання діалогу Церкви та держави на сучасному етапі розвитку України.

Метою статті $\mathrm{e}$ аналіз інформаційно-комунікативної політики як інструменту посилення взаємодії держави та Церкви на сучасному етапі розвитку українського суспільства.

Виклад основного матеріалу. Вивчаючи важливі аспекти державного управління у сфері релігії, головні напрями соціального вчення християнства в контексті місії Християнських Церков, важливо зупинитися на гострій актуальній богословській проблемі самої церковної місії. У даному випадку йдеться не лише про зміст церковного проголошення Євангелія у храмі, не лише про те, що Церква проповідує серед парафіян, а про те, що необхідно зробити богословській науці для того, щоб церковна проповідь в сучасних умовах була життєвою, зрозумілою, дієвою, актуальною та затребуваною сучасним суспільством. Адже християнська теологія є не лише філософським заглибленням у догматику, канонічне право, моральне вчення Церкви. Теологія - це особливе звіщення Церквою істини, думки Бога про людину, природу та світ. Саме тому, донести зрозумілою мовою до сучасної людини основні аспекти соціальної думки християнства, які торкаються питань політики, державотворення, геополітичних інтересів, економіки, права, інформаційного розвитку та всебічних процесів сучасної комуні- кації - важлива умова плідної місії Церкви в сучасному світі.

Зазначимо, що $з$ нашої точки 3оpy, нова парадигма українського державотворення мусить враховувати не лише досягнення філософії, політології, державного управління, економіки, публічного адміністрування, але й теологічну думку, релігійні процеси розвитку суспільства. Йдеться про формування нової духовної парадигми державотворення. Iї̈ серцевиною має бути розуміння цілісності духовного і матеріального життя сучасної людини, яке гармонічно пов'язане $з$ богословською категорією буття, усвідомлення духовної місії людини, з утвердженням значення духовних ідеалів, моралі, релігійних цінностей у формуванні й реалізації державної політики та здійснення державного управління. Саме про це говорить верховний архієпископ, Глава і Отець УГКЦ Блаженніший Святослав (Шевчук): “Нині в Україні ми є свідками народження чогось нового. Це породжує оптимізм, адже є ліпшим від того, що було вчора... Держава відкриває своє християнське коріння й хоче керуватися суспільним ученням Церкви, яке водночас є інструментом євангелізації суспільства" [2, с. 17].

Богословський підхід в державному управлінні передбачає конструктивний діалог світської науки та церковних інститутів. Отже, аналіз наукових розробок світських вчених свідчить про те, що поняття “комунікація” є предметом дослідження сучасної науки. Але питання впливу церковної комунікації на становлення сучасної української держави та розвиток громадянського суспіль- 
ства в Україні ще не стали особливим об'єктом наукових досліджень церковних науковців. Отже, актуальність вивчення проблем інформаційно-комунікативної політики як інструменту посилення взаємодії держави та Церкви не викликає сумніву.

На нашу думку, подальше поглиблення комунікації Церкви та держави починає залежати від інформаційно-комунікативних технологій. Саме вони активізують розвиток інноваційних засобів церковної проповіді, взаємодії священнослужителів та парафіян, політичних інститутів i релігійних громад. Звичайно, насамперед йдеться про Інтернет, соціальні мережі й інші електронні засоби комунікації. Вочевидь, що сучасні процеси глобалізації, інформатизації, розвиток сучасних комп'ютерних технологій створили фундамент принципово нової системи комунікативних зв'язків Церкви, держави, суспільства. Нові системи комунікацій впливають і на богословське осмислення реалій буття людства. Інтерес до всебічного вивчення досягнень сучасної теологічної думки світу обумовив використання й адаптацію церковними інститутами та громадами інформаційно-комунікативних технологій. Церковна соборність, спілкування, молитовне єднання, обговорення реальних існуючих церковних проблем життя християнина постійно потребують ефективних засобів взаємодії Церкви, громадянського суспільства 3 державою.

Зазначимо, що в церковному житті України, на відміну від Росії, християни (пересічні парафіяни) намагаються встановити діалог між церковною ієрархією, священиками та мирянами. Запровадити в церковній комунікації рівноправний обмін богословськими думками 3 приводу життя парафій, автокефалії, самостійності Церков, дати певну відверту християнську оцінку політичним явищам і процесам державотворення, національного будівництва, насамкінець узгодити соціальні реалії українського соціуму з біблійним одкровенням, християнською теологією та мораллю. Знані науковці Є. Романенко, В. Козаков, О. Рашковська, В. Ребкало, І. Чаплай наголошують: “Особливе значення при цьому мають воля політичних, релігійних та інших переконань, свобода слова, а також право й можливість безперешкодно висловлювати свою думку, вільно шукати, одержувати й поширювати різного роду інформацію й ідеї незалежно від державних кордонів, якщо вони не суперечать гуманістичним принципам" [1, с. 57].

Виходячи з вищевикладених роздумів, зазначимо, що релігійне життя суспільства, як і окремі події в житті людини, значною мірою залежать від особистої праведності, релігійних настанов релігійних інститутів та богословських поглядів на світ. На нашу думку, державному управлінню слід здійснювати вивчення основ життя соціуму саме через дослідження релігійної поведінки людей, їхнього внутрішнього світу [3, 4]. Це означає, що неможливо пояснити поведінку людини одним лише безпосереднім впливом на людську особистість політики, економіки, ідеології та біологічних явищ природи. Навіть історія людства доводить, 
що обставини можуть бути одні й ті самі, а поведінка людей різною. Тому християнське богослов'я вивчає багатий та складний внутрішній світ людини та іï духовні настанови поведінки і може суттєво збагатити сучасні наукові розробки у галузі державного управління.

3 точки зору церковної комунікації та християнського вчення про світ, зовнішнє середовище впливає на людину, але кожна людина реагує на зовнішні стимули залежно від власних духовних уявлень про світ, моральні цінності, основою яких для християнина є віра в Бога. Не складно помітити, що певним духовним явищам у житті Церкви, важливим подіям в історії людства передують відповідні духовні уявлення про Бога, Церкву, світ і суспільство. Християнська соціальна думка вбачає розвиток суспільства у творенні та утвердженні Правди Божої. Християнство є реальною силою та духовним багатством життя соціуму [5; 6].

Таким чином, цілком слушно, що науковці, які займаються питаннями державної інформаційно-комунікативної політики у сфері релігії, вивчають питання божественної справедливості в житті людства, вищих духовних смислів буття, кардинальної трансформації всього світу у контексті релігії. I науковцям необхідно показати реальний вплив цих духовних цінностей на побудову справедливого суспільства, заснованого на релігійних уявленнях сучасної людини. Православ'я, згідно із соціальною думкою християнства, має об'єднати суспільство у процесах облаштування всіх сфер людського буття у світлі Євангелія, але з ураху- ванням реальних сил гріха та духовного поневолення.

Дослідники змушені визнати, що не всі люди живуть за законами любові, милосердя й пробачення, як цього вимагає християнська мораль. Але це не означає, що проповідь Церкви Христової є утопічною та нереалістичною в цьому земному світі. Якби закон любові не домінував у людських взаєминах, то суспільство припинило б існувати й розвиватися. Християнство для релігійного мислителя є релігією любові, в любові він вбачає сенс життя, ідеал духовної досконалості та основу суспільного буття. В історії етики та філософії існують різні погляди на походження та сутність моралі: одні вчені вважають, що людина за своєю природою є доброю і в ній немає жодного гріха, інші наполягають, що людина є твариною, а утвердження сили, волі та влади в соціумі є природним прагненням людської особистості. Для християнського богослова, служіння Богу, творіння добра, прагнення до добра, любов, світло, істина - це практика християнського життя, а не абстрактні теорії про моральність. 3 такої позиції, віра в Бога, служіння Церкви є цілком виправданим та духовно спасенним, визвольним для людини, сприятливим для іiї духовного зростання та суспільного розвитку [5; 6].

Бог, за вченням Церкви, посилає людині можливість удосконалити й одухотворити всю світобудову. Звідси в християнина світла віра у високі явища благодатного та доброчесного життя. Гріх - це, передусім, обмеженість людського буття, зубожіння чесноти, втрата цілісності життя й 
гармонії. Шлях суспільного розвитку, згідно з соціальною думкою християнства, пролягає через пустелю духовної боротьби, аскези, морального осмислення людського життя та відновлення християнського пошуку Бога. Духовний світ людини є відправним пунктом для всіх інших форм миру, які разом складають передумову для процвітання конкретної особистості та суспільства.

Цілком зрозуміло, що суспільство є сукупністю людей, об'єднаних конкретними інтересами, потребами або взаємними зв'язками та видом діяльності. I це означає, що вивчити діалог Церкви, держави та суспільства з більшим або меншим ступенем вірогідності можна лише на підставі досліджень складних зв'язків між складовими елементами суспільства. Важливо зауважити, що з одного боку, богословська думка християнства вписується в загальну, єдину систему сучасної науки, а з другого, вона має свої особливості та відмінні ознаки.

На нашу думку, сьогодні є всі підстави говорити про те, що християнське вчення про суспільство пояснює соціальні явища та духовні трансформації в світлі Божественного Одкровення - Святого Письма (Біблії) та Священного Передання Церкви [7, с. 304-334]. Нині богослов'я, мабуть, є єдиною системою людського знання, яка зберігає орієнтацію на Слово Боже. Соціологія, економіка, політологія і навіть право безповоротно відійшли до сфери емпірики. Перед християнською соціальною думкою стоїть завдання розкриття духовної історії людства, вищих смислів людського буття [2, c. 58-59]. Немає жодних сумнівів у тому, що духовна криза сучасної людини зумовлена занепадом моральності, згасанням релігійної віри та утилітаризмом. Церква сміливо й прямо говорить сучасному християнину про те, що через гріх увесь світ занурюється у прірву політичної облуди, ідеологічної брехні, пороку та обману. Перед лицем атеїзму та матеріалізму християнське богослов'я виступає в ролі повсякчасної духовної опозиції.

Незамінною підставою християнського вчення про суспільство є Святе Письмо та Священне Передання Церкви. Звернення до християнської соціології є одним 3 важливих напрямів православного богослов'я. Проте зазначимо, що, незважаючи на пріоритет соціальних тематик у наукових розробках певних християнських дослідників, висловлюється думка, що для молитви та духовного життя соціальна думка Церкви не є обов'язковою. Причому йдеться не стільки про критику процесів сучасного життя, скільки про вузькість, обмеженість уявлень деяких християн про суспільство. Більша частина цих облудних та викривлених уявлень про суспільство була успадкована християнами через сектантство, але багато хто навіть з благочестивих віруючих досі залишаються прибічниками соціальної ізоляції церковних парафій.

Наголосимо, що глибоке та уважне вивчення соціальної думки християнства, державної інформаційно-комунікативної політики у сфері релігії дає можливість науковцю у галузі державного управління побачити нові грані богословського вчення 
про суспільство. За богословською думкою Церкви стоїть величезна історія людства та соціальної дії християнства в історії, а не лише духовні роздуми про молитву та чесноти. Не випадково найкращі соціальні та релігійні мислителі людства завжди виступали проти пасивності християн та вітали всебічну діяльну участь християнина не лише у зберіганні та захисті істинного вчення Церкви, але й у багатогранних процесах суспільно-політичного життя.

Численні богослови, релігійні мислителі, роздумуючи над проблемами суспільного життя, церковної комунікації, питаннями діалогу Церкви та держави, зверталися не лише до Слова Божого, але й вивчали наукові політологічні й філософські розробки. Важливо нагадати, що з точки зору політичної теології, християнське вчення про суспільство, освітлене Євангелієм, звільняє життя наше від будь-якої політичної демагогії та ідеологічної маніпуляції. На сьогодні християнська соціологія вже одержала визнання в сучасній науці. Надруковано велику кількість книг, присвячених взаємодії Церкви та суспільства, християнства та держави, а дослідницька література, що зачіпає питання суспільствознавства, вже є надзвичайно широкою в науково-богословській рефлексії.

Зазначимо, що соціальна думка християнства $є$ цілісним ученням про суспільство, сполученим з етичною теорією християнської аскези та ідеєю виховання людської особистості у світлі Євангелія. За цією концепцією вчений оперує поняттями “чеснота”, “святість”, “любомудрство”, “послух” [2, с. 11-18]. Більш змістовно думки богословів про суспільство можуть бути представлені низкою понять та ідей, а саме:

- діяльне служіння людини Богу та ближньому;

- реальні справи милосердя та любові християнина в ім'я Бога;

- Церква Христова як Тіло Христове в житті суспільства.

В історії людства написано тисячі томів із соціології, філософії та проблем розвитку суспільства. Ще з давніх часів люди намагалися пояснити устрій суспільства, родини, держави, звернути увагу на динаміку міжособистісних взаємин та людські гріхи, що знищують гармонію життя соціуму. Тому й соціальна думка Церкви як науково-богословська дисципліна виникає на перетині соціальної філософії та морального богослов'я. Життя Церкви та суспільства облаштовують люди, при цьому у своїй повсякденній мирській та церковній діяльності вони керуються духовними ідеалами, моральними принципами, релігійними уявленнями про Бога, світ і людину [8].

\section{Висновки та перспективи подаль-} ших досліджень. Попри значне удосконалення державної інформаційно-комунікативної політики у сфері релігії за останні роки, науковці так і не позбулися певних атеїстичних уявлень про роль та значення релігії у житті суспільства. Тому виникає необхідність переглянути існуючі підходи державного управління до релігії та церковного життя, застосувати нові моделі, за допомогою яких можна забезпечити партнерські взаємовідносини між Церквами, територіальними громадами та органами державного управління. Державне 
управління має бути більш інтегрованим у релігійну проблематику, динамічно розглядати діалог науки та релігії, тобто не відставати від реалій сучасного життя, при цьому передбачаючи духовні процеси церковної комунікації, спрямовуючи та прокладаючи шлях до їх реалізації на користь демократичного суспільства.

Iз зазначеного можна дійти кількох висновків загального характеру. Можливість мирянами безпосередньо брати участь в обговоренні церковних проблем, питань розвитку держави, а органам державної влади взаємодіяти з релігійними громадами щодо вирішення широкого спектра соціальних, економічних і правових проблем парафій - є свідченням нової конструктивної політики держави у сфері релігії. Отже, певні позитивні духовні реформування життя багатьох церковних парафій, демократизація суспільного життя України пов'язуються з інноваційними інформаційними процесами та розвитком комунікації. Це робить сучасне церковне життя більш мобільним, дієвим, живим і доступним для сучасної людини. При цьому, варто додати, що в демократичних державах постійно відбувається взаємодія Церкви, держави й громадянського суспільства.

Місіонерство, служіння Церкви в сучасному суспільстві неможливе без відповідних соціальних дій, розробки концепції церковної комунікації, спілкування духовенства 3 науковцями. 3 позиції суспільствознавства спілкування є стосунками сторін, спрямованими на досягнення певної мети. Цілком очевидно, що церковна проповідь, звернена до сучасника має враховувати не лише вчення Церкви про суспільство, але й низку соціальних чинників:

- сенсову частину, тобто те, для чого, власне, взаємодія Церкви, держави та суспільства здійснюється, що є метою діалогу Церкви та держави, церковних інститутів та громадянського суспільства;

- структуру, що виявляє себе в певній формі, в якій взаємодія Церкви та суспільства, власне, й відбувається;

- конкретні дії священнослужителів, завдяки яким здійснюється діалог Церкви та суспільства.

Ефективна церковна комунікація, яка відбиває взаємодію Церкви та держави, забезпечується лише в умовах процесів демократії, розвитку інформаційних технологій та процесу інформатизації соціально-політичних відносин сучасного світу. Тобто наявність процесів модернізації, становлення соціального служіння Церкви, богословської просвіти, діалогу науки та релігії, високого рівня розвитку інформаційних технологій $\epsilon$ необхідним елементом розвитку взаємодії Церкви та держави.

\section{СПИСОК ВИКОРИСТАНИХ ДЖЕРЕЛ}

1. Козаков В. М. Державно-громадянська комунікація: шлях від кризи до взаємодії: монографія / [В. М. Козаков, О. В. Рашковська, В. А. Ребкало, Є. О. Романенко, І. В. Чаплай]. Київ: ДП "Вид. дім "Персонал", 2017. - 288 c.

2. Блаженніший Любомир. Думки у спадок / Упоряд. Ольга Гнатишин. Львів: Свічадо, 2018. - 112 с. 
3. Кирило (Говорун), архім. Українська публічна теологія. - К.: Відкритий Православний Університет Святої Софії-Премудрості, Дух і Літера, 2017. - $144 \mathrm{c}$.

4. Слово про свободу й відповідальність. Ініціативна група "Першого грудня” в документах і текстах. Упорядники: Олена Шарговська, Ярина Ясиневич. - К.: Дух і Літера, 2018. - 424 c.

5. Мартишин Діонісій, прот. Зустріч із Живим Богом: духовні бесіди на православні свята / Д. Мартишин. - К.: Духовно-просвітницький Центр імені Святих Апостолів, 2013. - 104 c.

6. Мартишин Діонісій, прот. Пошуки духовного вектора суспільного розвитку пострадянських країн: постановка проблеми // Православ’я - цивілізаційний стрижень слов'янського світу: Зб. наук. праць / Ред. колегія: П. П. Толочко (головний редактор), О. П. Моця (відповідальний редактор) та ін. К.: Фенікс, 2011. - С. 248-255.

7. Балог П. Віра шукає розуміння / Петро Балог. - К.: Кайрос, 2018. 398 c.

8. Мартишин Д. С. Богословські аспекти проблематики діалогу релігії та науки в умовах процесів глобалізації // Проблеми модернізації України: [Зб. Наук. пр.] Вип. 6. Матеріали Міжнар. наук.-прак. конф. "Проблеми культури наукової роботи та академічної доброчесності у сучасному світі”, м. Київ, МАУП, 26 березня 2018 р. / Редкол.: М. Н. Курко (голова) [та ін.] - К.: ДП “Вид. дім “Персонал”, 2018. С. 54-56.

\section{REFERENCES}

1. Kozakov V. M., Rashkovska O. V., Rebkalo, V. A., Romanenko, Ye. O.,
Chaplai, I. V. (2017). Derzhavno-hromadianska komunikatsiia: shliakh vid kryzy do vzaiemodii [State and civil communication: the path from crisis to interaction]. Kyiv: DP "Vyd. dim "Personal" [in Ukrainian].

2. Blazhennishyi Liubomyr. (2018). Dumky u spadok [Thoughts inherited]. O. Hnatyshyn (Eds.). Lviv: Svichado [in Ukrainian].

3. Kyrylo (Hovorun), archimandrite. (2017). Ukrainska publichna teolohiia [Ukrainian Public Theology]. Kyiv: Vidkrytyi Pravoslavnyi Universytet Sviatoi Sofii-Premudrosti, Dukh i Litera [in Ukrainian].

4. Sharhouska, O., Yasynezych, Ya.(2018). Slovo pro svobodu y vidpovidalnist. Initsiatyvna hrupa "Pershoho hrudnia” v dokumentakh i tekstakh [The word about freedom and responsibility. Initiative group " Pershoho hrudnia" in documents and texts]. Kyiv: Dukh i Litera [in Ukrainian].

5. Martyshyn Dionisii, protoiereus. (2013). Zustrich iz Zhyvym Bohom: dukhovni besidy na pravoslavni sviata [Meeting with the Living God: Spiritual Conversations on Orthodox Feasts]. Kyiv: Dukhovno-prosvitnytskyi Tsentr imeni Sviatykh Apostoliv [in Ukrainian].

6. Martyshyn Dionisii, protoiereus. (2011). Poshuky dukhovnoho vektora suspilnoho rozvytku postradianskykh krain: postanovka problemy [The search for the spiritual vector of social development of the post-Soviet countries: the statement of the problem]. Pravoslavia - tsyvilizatsiinyi stryzhen slovianskoho svitu - Orthodoxy - a civilization core of the Slavic world, 248-255 [in Ukrainian].

7. Baloh, P. (2018). Vira shukaie rozuminnia [Faith seeking understanding]. Kyiv: Kairos [in Ukrainian].

8. Martyshyn, D. S. (2018). Bohoslovski aspekty problematyky dialohu re- 
lihii ta nauky $\mathrm{v}$ umovakh protsesiv hlobalizatsii [Theological aspects of the dialogue of religion and science in the conditions of globalization]. M. N. Kurko, et. al. (Eds.). Problemy kultury naukovoi roboty ta akademichnoi dobrochesnosti u suchasnomu sviti - Problems of the culture of sci- entific work and academic integrity in the modern world: Proceedings of the scientific-practical conference. (Vols. 6. Problemy modernizatsii Ukrainy - Problems of modernization of Ukraine), (pp. 54-56). Kyiv: DP "Vyd. dim "Personal" [in Ukrainian]. 